\title{
IAGR 2011: Annual Convention and 8th International Symposium on Gondwana to Asia - Supercontinent Dynamics: India and Gondwana
}

\section{6-28 August, 2011, Hyderabad, India}

As part of its Golden Jubilee Celebrations, the National Geophysical Research Institute (NGRI) and the Council of Scientific and Industrial Research (CSIR), India, organized the 2011 annual convention of the International Association of Gondwana Research (IAGR), and the $8^{\text {th }}$ International Symposium on Gondwana to Asia at Hyderabad under the major theme "Super Continent Dynamics: India and Gondwana" during August 26-28, 2011. The meeting registration and ice-breaker took place on the evening of August 26 ${ }^{\text {th }}$. The conference was formally inaugurated on August $27^{\text {th }}$ by Prof. Harsh K. Gupta, President of the IUGG, followed by a brief report on the IAGR activities by Prof. M. Santosh, Secretary General, IAGR. The conference format included three technical sessions of oral presentations, and a poster presentation that was open on both days of the conference. This was followed by a field excursion to provide a glimpse of the geology of the Eastern Dharwar craton during 29-30 August, 2011.

The first technical session on the "Early history of cratons: structure, composition and dynamics", was chaired by Professors M. Yoshida and C. Leelanandam. The session was multidimensional in scope, with both geological and geophysical components. The tenor was reflected in the two key-note talks, the first by Y.J. Bhaskar Rao on the "Perspectives on evolution of Archaean cratonic mantles with insights into the south Indian craton", that tried to reconcile the available petrological and geochemical information on the Indian sub-continental mantle with geophysical data. The second key-note address by S. S. Rai argued from seismological evidence that the crustal structure below the eastern and western Dharwar cratons could be the result of an Archaean equivalent of a Himalaya-Tibettype orogeny. The remaining talks focused on deciphering the crustal and lithospheric

structure of the Indian shield using a variety of geophysical techniques. Sukanta Roy demonstrated that the Dharwar craton had lower heat flow than the Aravalli, Singhbhum and Bastar cratons, largely because of a radiogenic upper crust that overlies a relatively cold mantle with low Moho temperatures. Ravi Kumar et al. observed delays in arrival times of Ps conversions from the $410 \mathrm{~km}$ and $660 \mathrm{~km}$ discontinuities below peninsular India, that indicate either higher mantle temperatures or a thinner high velocity lid in the Indian cratons. Integrated modeling of topography, gravity, geoid and heat flow data by Niraj Kumar et al. suggests that the

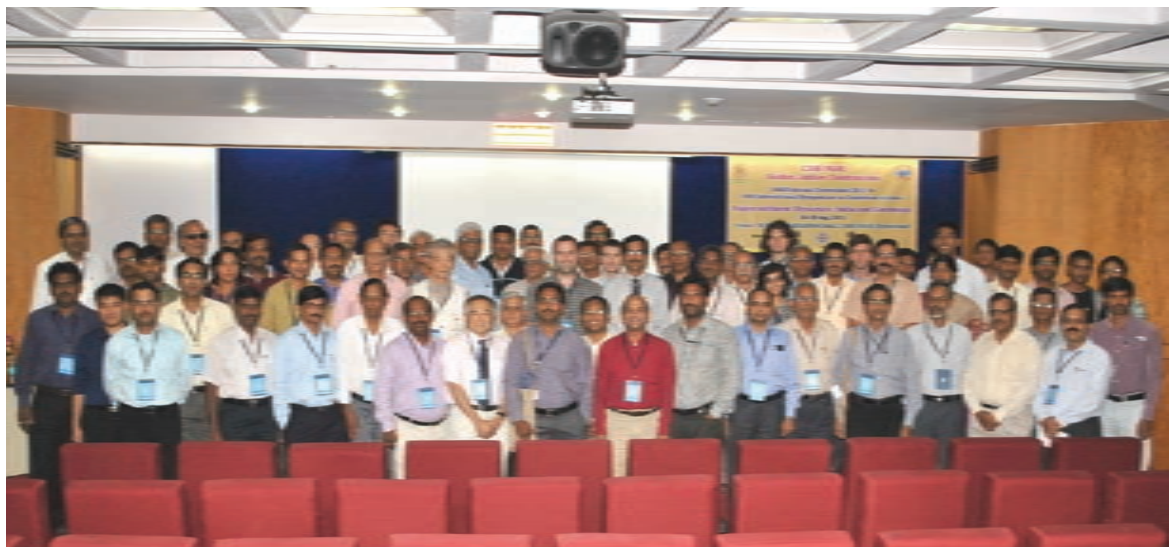

IAGR meeting 2011, NGRI, Hyderabad. 
Indian cratonic crust is $\sim 40 \mathrm{~km}$ thick, with the lithospheric thickness varying from $90 \mathrm{~km}$ below the Indian Ocean, to $120 \mathrm{~km}$ below the Southern Granulite Terrain (SGT) and 190 $\mathrm{km}$ beneath the Dharwar craton. Sain and Sarkar applied pre-stack depth migration to seismic migration data in the Kutch region, and inferred that crustal depths increased from $35 \mathrm{~km}$ near the coast to $45 \mathrm{~km}$ near the epicentral region of the Bhuj earthquake (2001) thereby refuting rift-related thinning of the crust in this region. Vijaya Rao and Sarkar used seismic images, structure and composition of deep crustal probing to understand lithospheric evolution as a consequence of supercontinental dynamics, while Pandey attempted to explain intraplate seismic activity in the Indian shield as a consequence of sustained exhumation of the upper crust and emplacement of a high velocity mafic layer at the Moho that led to enhanced mantle heat flow and weakening of the continental crust.

The second technical session on "Building and Breaking of Supercontinents with focus on Gondwana" covered the remainder of Day 1 and the first half of day 2. The first part of the session was chaired by Professors Alan Collins and R.N. Singh, and was initiated with a key-note by M. Santosh on "Making and breaking continents, cratons and supercontinents". Amarasinghe and Collins presented new LA-ICPMS age data

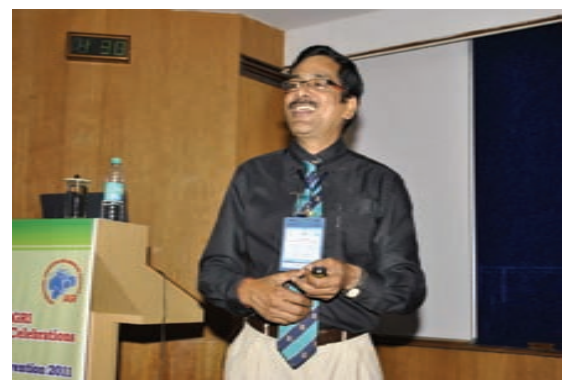

Keynote address by Prof. M. Santosh

from cores and rims of detrital zircons from the Wanni and Highland Complexes of Sri Lanka that dispute their existing status as distinct terranes. K.S. Misra correlated the culmination of the Gondwana deposition in India with Cretaceous volcanism, while G. Parthasarathy demonstrated how crystal parameters of graphite could be used to constrain peak metamorphic temperatures in the Southern Granulite Terrain and the Eastern Ghats belt. S. Mohanty suggested that the Bastar and Yilgarn cratons along with the Napier Complex formed a supercontinental block "Siwa" at around $2400 \mathrm{Ma}$, that broke up around $2000 \mathrm{Ma}$; E.V.S.S.K. Babu

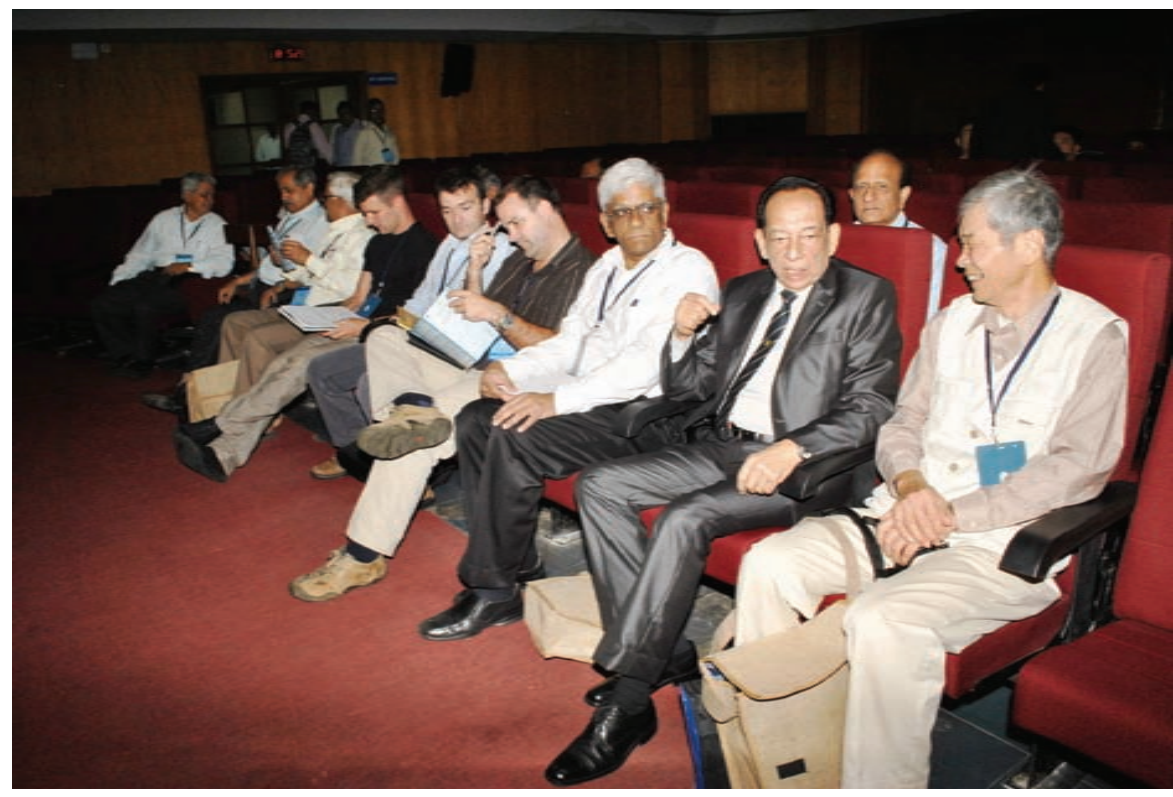

Delegates interacting at the meeting.

presented an interesting set of data from U$\mathrm{Pb}-\mathrm{Hf}-\mathrm{O}$ isotopic studies that indicate 3.03.3 Ga and 2.3-2.6 Ga age clusters of detrital zircons from the western part of the Cuddapah basin, at odds with the existing age datasets for the Eastern Dharwar craton basement. Naresh Kochhar speculated on the existence of a Late Proterozoic Malani supercontinent comprising the Trans-Aravalli and various other continental fragments including parts of Siberia, Mongolia and Kazakhstan.

The second half of Session 2 began with a key-note by Prof. Ian Fitzsimons on "Bits and Pieces: Pan African Granites and the Assembly of Gondwana", in which he emphasized the uncertainty in the location of the Pan-African sutures along which Gondwana was assembled. In contrast, M.V. Ramana et al. analyzed marine magnetic data related to India-Antarctica separation during Gondwanaland break-up, and identified M0 to M11 magnetic anomalies in the Bay of Bengal and the Enderby basin in east Antarctica that suggest the presence of extinct spreading ridges in both the basins. Subba Rao and Hussain suggest continuity between the Central Dronning Maud Land, East Antarctica and the Mozambique belt, based on the similar tectono-metamorphic imprints on the Proterozoic anorthosites in both the terranes. Tsunogae et al. provided a documentation of $\mathrm{CO}_{2}$ as the dominant fluid phase during UHT metamorphism in both East Antarctica and Southern India. Based on heat production and thermal conductivity data collected from the Eastern Ghats belt. Barker et al. suggested that UHT conditions could have been attained in the EGB crust simply by burial of the presently exposed rocks. Venkateshwarlu et al. demonstrated compatibility between magnetic polarity stratigraphy and biostratigraphy in the Cauvery basin during the late Cretaceous. D. Gopala Rao highlighted the need to understand the physical processes and mechanism for the origin of the anomalously shallow ( 900 $\mathrm{m})$ and deep ( $6400 \mathrm{~m})$ parts of the Central Indian Ocean.

Following a superb banquet dinner on the evening of August 27, Session 2 resumed the next morning with Professors M. Santosh and K.S. Mishra in the chair. The session began with an extremely stimulating key-note talk on the 700 million year geotectonic history of the Japanese Islands by Yukio Isozaki. Masaru Yoshida et al. presented U-Pb zircon ages that confirm the presence of a PanAfrican thermal imprint in gneisses of the Nepal Higher Himalayan Crystalline Sequence, prior to the Miocene Himalayan metamorphism. From a multichronological study of granitoid basement samples from southern Kyrgyzstan, S. Glorie convincingly demonstrated repeated reactivation of the Late Paleozoic South Tien Shan suture zone into the Cenozoic Era. Based on their transportparallel balanced cross-section across the Rangit window in the Sikkim Himalaya, Kathakali Bhattacharyya et al. argued that the Gondwana basin, in the window, must once have extended at least $150 \mathrm{~km}$ northward of its present northernmost exposure. Ram Mohan et al. used geochemical and isotopic data from the Sittampundi anorthosite to indicate the operation of a Palaeoproterozoic, Pacific-type subduction-accretion system in 
this region. Yellapa et al. reported the presence of two temporally distinct ophiolites in the Cauvery Suture Zone that suggest closure of two different oceans in the Neoarchaean and the Neoproterozoic.

The first part of Technical Session 3 on "Orogenic belts, sedimentary basins and resources" was chaired by Prof. Sanghoon Kwon and Dr. U. Raval. Alan Collins et al. delivered a key-note lecture, reporting new $\mathrm{U}-\mathrm{Pb}$ and $\mathrm{Hf}$ zircon isotopic data that indicates an age discrepancy between the eastern and central parts of the Eastern Ghats Province. T.R.K. Chetty highlighted the complexities and connections in the Proterozoic high grade metamorphic orogens of south India, while Saibal Gupta argued that orogenic processing during discrete thermal events had significant impact on the strength of the Eastern Ghats lithosphere. Rajesh and Arai interpreted geochemical information on the Fe-Ti-P gabbros in the Achankovil Shear Zone as a consequence of rifting during Gondwanaland break-up, while Narsimha Reddy considered the Chimalpahad Layered Complex in the Khammam schist belt as a Neo-Archaean to Palaeoproterozoic suprasubduction zone. Finally, Sunder Raju used textural and compositional data to examine the crystallization history of chromite and rutile in the Sittampundi Anorthosite body.

The second part of Session 3 was initiated with a key-note lecture by Prof. Dilip Saha, who discussed the evolution of the northern margin of cratonic India through the Palaeoproterozoic to the Cenozoic based on structural studies in the Lesser Himalyan Proterozoic sequences in the eastern Himalaya of Sikkim and Arunachal Pradesh. Purnachandra Rao et al. discussed the crustal structure of the Himalayan collision zone and southern Tibet based on Pnl waveform modeling and surface wave dispersion studies. V.M. Tiwari et al. derived a density model along a profile in the NW Himalaya that suggests crustal thickening of the Indian plate by about $30 \mathrm{~km}$ as it subducted below the Eurasian plate, with the effective elastic thickness decreasing northwards. Devajit Hazarika used receiver function analysis to constrain crustal thickness and velocity structure below the Tidding suture close to the Eastern Himalayan syntaxis. Rao and Mall suggest underplating in the Krishna-Godavari basin as a possible cause for the doming of the upper crust, formation of a detachment fault in the mid-crust and flattening of the Moho. Gravity modeling in the Chintalapudi sub-basin of the Pranhita-Godavari valley was used by J.V. Rama Rao et al. to identify prospective coal deposits. Behera and Sarkar used tomographic imaging to delineate the presence of an Early Cretaceous Volcanic Province below the Mahanadi Gondwana basin. Concluding the session, R.C. Patel et al. presented results of apatite fission track dating that could be used to calculate uplift rates in the Raniganj basin.

The poster session was open on both days of the conference, and therefore provided enough time for interaction. The student poster by D.P. Mohanty and T.R.K. Chetty (Zone of detachment at the NW margin of Kanjamalai Hills, Cauvery Suture Zone: implications to accretion tectonics) was adjudged to be the best and was presented with the IAGR Best Student Poster Award. The last evening of the conference included a plenary discussion with the interaction of all the participants. The plenary discussion highlighted the need for a better integration of geophysical and geological data to sort out the geodynamic issues involving Gondwana and India. In all, the conference was extremely useful as an academic forum and exercise, and provided many young researchers with the opportunity of interacting with experts in their field. The organizers in the NGRI deserve special appreciation for the efficiency with which the whole conference was conducted.

\section{Field Excursion}

Following the tight schedule of the 3-day conference at Hyderabad, about 20 delegates of the IAGR Convenetion 2011, took part in a geological excursion in the Eastern Dharwar craton, under the able leadership of E.V.S.S.K. Babu, T. Vijaya Kumar, and A.P. Singh of NGRI, Hyderabad. Shri K. Chandrasekhar of GSI, Hyderabad acted as a senior instructor in the field. The excursion was planned to provide a quick, $150 \mathrm{~km}$ long traverse through the Eastern Dharwar craton which hosts late Archaean to Mesoproterozoic geological records indicating a complex tectonic history.

The field party started from the NGRI guest house at around $8 \mathrm{AM}$ and drove southeastwards along Hyderabad-Nagarjun Sagar road. The first stop at $\sim 45 \mathrm{~km}$ from Hyderabad provided a glimpse of an E-W trending large, mafic dyke belonging to a suite of mafic dyke dyke swarms that cut across the granite-gneiss terrain in Eastern Dharwar. This massive dyke showing a fairly coarse aggregate of $\mathrm{Cpx}+\mathrm{Plag} \pm \mathrm{Amp}$ is yet to be studied thoroughly for geochemical and geochronological details to better constrain there tectonic evolution. The next stop, 60 $\mathrm{km}$ from Hyderabad, was meant to provide an excellent roadside exposure of the gray granite gneiss with enclaves of amphibolites providing a hall mark of the HyderabadDevarakonda granite. The foliated Bt-Hbl bearing granite gneiss hosts up to metre size enclaves of Bt-Amp-Epdt bearing amphiolites with folded foliation cut by late granitic veins. The granite gneiss also hosts metre size enclaves of dark gray, massive tonalite/ granodiorite.

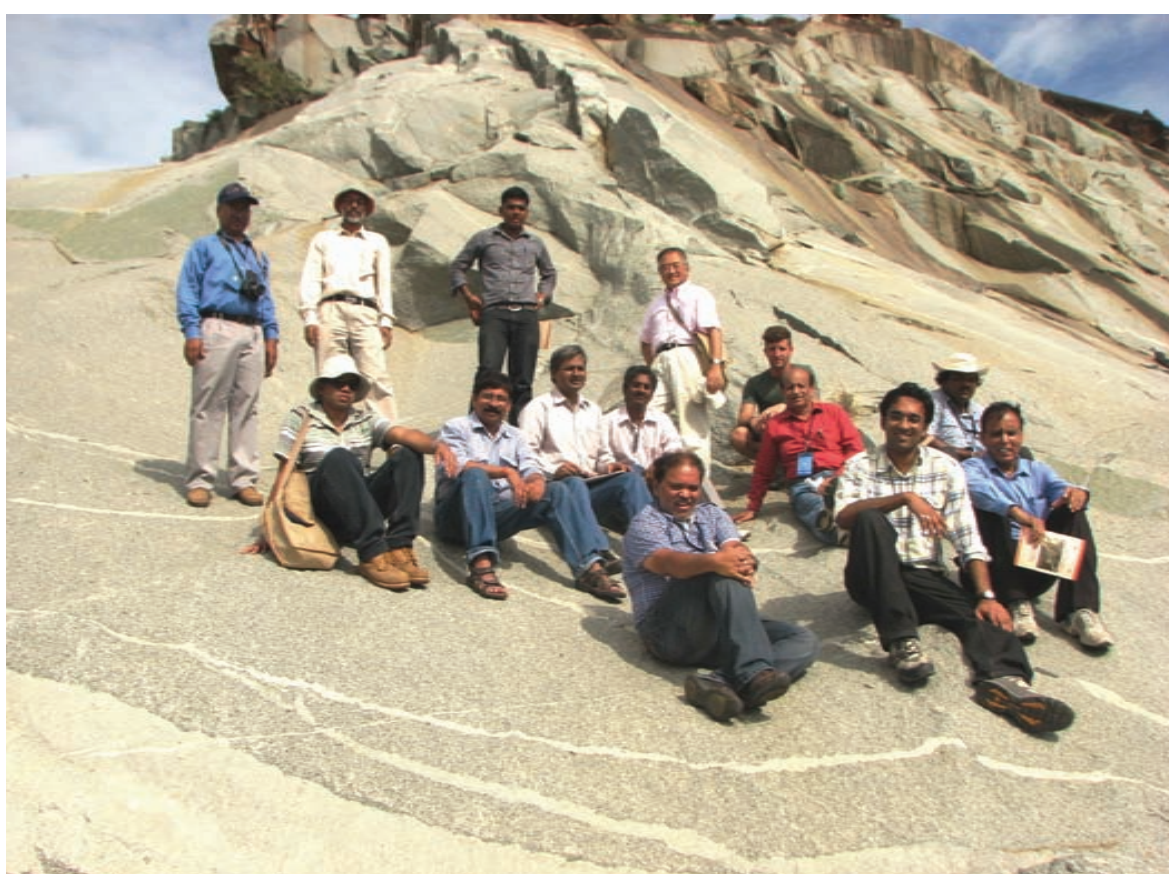

Participants on the slopes granite quarry off Vijaya Bihar, Nagarjun Sagar. 
The next stop provided further glimpse of the fabric in the gray granite gneiss, and the younger massive granite that invades the gray gneiss. Following a break for packed lunch on the outskirts of Peddavuru, our next attraction was the Peddavuru schist belt. Although mafic schist belts are more common and extensive in the southwestern part of the Eastern Dahrwar craton, e.g. the Kadiri, Ramgiri, Kolar, the NNW trending Peddavuru schist belt extends for over 50-60 km along strike with width varying between $10 \mathrm{~m}$ and $100 \mathrm{~m}$. The main rock is a metabasalt with a steep schistose foliation, traversed by 5-10 $\mathrm{cm}$ thick granitic dykelets which are generally parallel to foliation but locally cross-cutting the schistosity. The relict flow bands in the mafic schist show tight folds appearing as intrafolial folds. The relatively thicker granitic dykelets are boudinaged suggesting overall flattening fabric in the belt. In a neighbouring outcrop we examined the $\mathrm{L}=\mathrm{S}$ granitoids which commonly occur at the boundary of the schist belt. The granitoids are full of decimetre size mafic microgranular enclaves. The long dimension of the enclaves are often aligned parallel to the over all granitoid fabric. Flat, lensoid epidote bearing cherty enclaves seen in this outcrop, usually show a rim with concentration of $\mathrm{Hbl} \pm \mathrm{Bt}$ indicating metasomatic reactions with surrounding magma.

The field party then moved to a quarry with excellent outcrop of gray granite cut by several sets of aplitic dykes. The outcrop also shows effect of brittle deformation in the Eastern Dharwar manifest as brittle fractures which offset the aplitic dykes and veins. Close to this quarry, the participants observed from a distance the mesa topped by the flat lying Srisailam Quartzite unconformably overlying the granite gneiss with steep foliation and keels of the schist belt.

By late afternoon we checked in Vijaya Vihar, and enjoyed tea with cool breezes coming from the huge Nagarjun Sagar reservoir. The evening was spent in the grandeur of the Ethipothala falls. A spectacular gorge here cuts through the Srisailam Quartzite, the stream water draining into the Krishna River from its right bank. As explained by the leaders, N-S trending

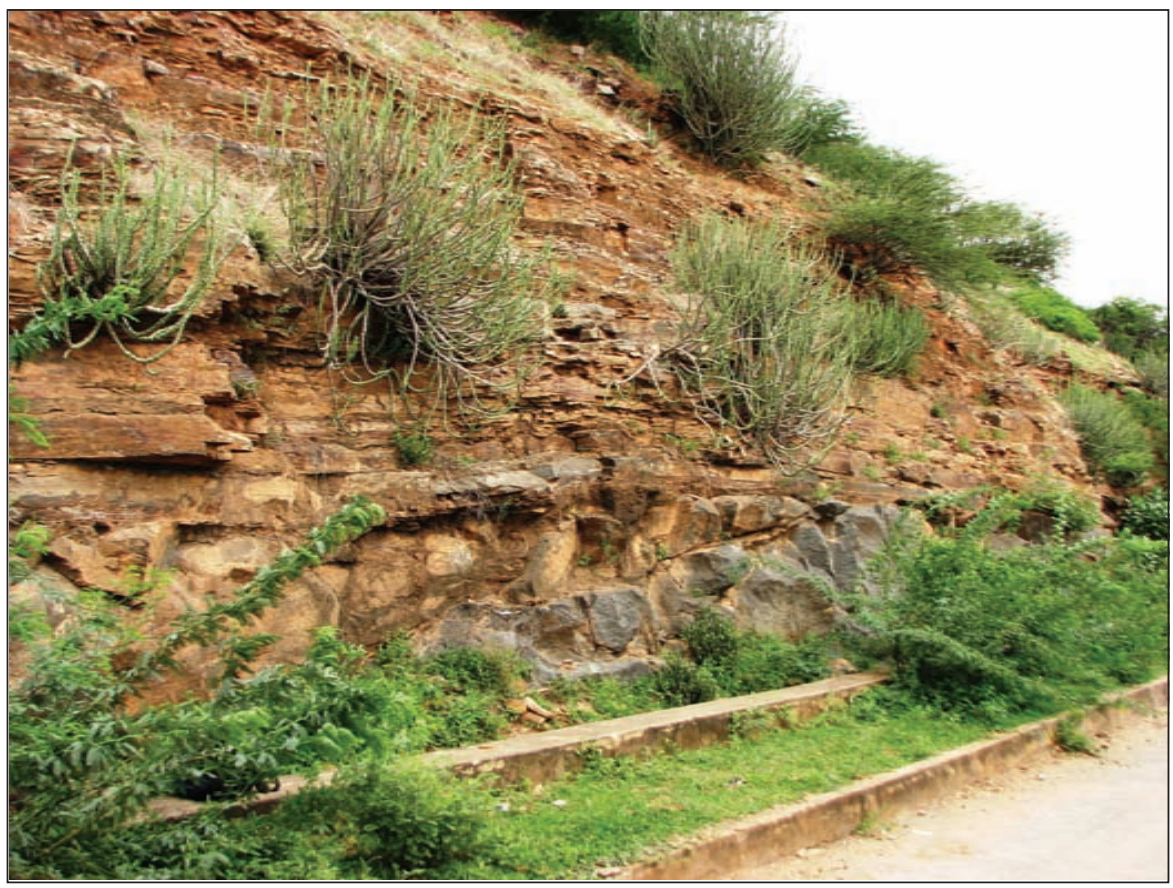

Srisailam Quartzite in sharp contact with the basement granitoids, right bank of Nagarjun Sagar Dam.

faults here control uplift of the basement rocks including some BIF bands as a constituent of the schist belt.

Refreshed and invigorated by the warm food and hospitality at Vijaya Vihar, and a good night's sleep the field party prepared for the final field stop next morning. We drove to the Nagarjun Sargar Dam across the Krishna River to reach the scheduled spot on the southern embankment of the dam. Here the flat lying Srisailam Quartzite unconformably overlies the Peninsular gneissic complex (Dharwar batholith). The basement on the right bank of Krishna River here consists of a gabbroid body laterally replaced by a hornblende bearing granitoid with $\mathrm{L}=\mathrm{S}$ fabric and common microgranular enclaves. The contact with overlying gritty sandstone with thin wavy bedded silty/fine sandstone intercalations here shows undulations on $10 \mathrm{~m}$ scale, suggesting drowning of paleotopography during the deposition of the Mesoproterozoic Srisailam Quartzite.

Finally, the participants had an opportunity to visit the Nagarjun Sagar Dam, the world's largest masonry dam standing tall at $150 \mathrm{~m}$ and having a length of $1.6 \mathrm{~km}$, courtesy the Irrigation Department of the Andhra Pradesh Government. The delegates not only had a birds' eye view of the exposed river bed of mighty Krishna from the restricted driveway atop the dam, they were also given a tour through the innards of the dam above one of the huge gates close to the left bank.

Post-lunch the field party drove back to NGRI, Hyderabad ruminating over the exciting field trip! On the whole, the geological excursion, well planned and executed by the organizers, opened new vistas to participants who are not familiar with the geology of the Eastern Dharwar craton.

\section{Saibal Gupta}

Department of Geology \& Geophysics,

Indian Institute of Technology,

Kharagpur - 721302, India

\section{Dilip Saha}

Geological Studies Unit

Indian Statistical Institute,

Kolkata - 700 108, India

E: sahad.geol@gmail.com 